This is a self-archived version of an original article. This version may differ from the original in pagination and typographic details.

Author(s): Saresma, Tuija

Title: The Concept of Love in Masculinist Blogs : A Strategic Ideal

Year: 2018

Version: Accepted version (Final draft)

Copyright: (c) Brill/Rodopi, 2018.

Rights: In Copyright

Rights url: http://rightsstatements.org/page//nC/1.0/?language=en

Please cite the original version:

Saresma, T. (2018). The Concept of Love in Masculinist Blogs : A Strategic Ideal. In D. Byrne, \& W. Y. Ade (Eds.), Fluid Gender, Fluid Love (pp. 108-126). Brill Rodopi. At the Interface / Probing the Boundaries, 108. https://doi.org/10.1163/9789004380233_008 


\title{
The Concept of Love in Masculinist Blogs: A Strategic Ideal
}

\author{
Tuija Saresma
}

\begin{abstract}
Love is often considered a positive emotion and an ethical relationship between people. The representations of love in contemporary culture usually emphasise its beneficial, even empowering effects. However, the fluidity of the concept also enables other kinds of representations of love to flourish. For example, the advocates of traditional gender order — masculinists or male rights activists (MRAs)-_ use idealistic images of heterosexual love, often intertwined with the idealised heterosexual nuclear family, to promote repressive ideologies such as misogyny and antifeminism. This is increasingly done with the help of internet sites. In this chapter I wish to show that the fluidity of the concept of love enables various strategic uses of the ideal of love. I deconstruct love as a utopian force by critically analysing its strategic usages on the internet. Inspired by multidisciplinary cultural studies and feminist studies, I apply rhetorical analysis in close reading of discourses about love on a male activist site. My hypothesis is that love is used as a repressive, heteronormative ideology in an attempt to re-position women and men within the traditional, rigid gender order. In my reading of the Angry Harry website, which is explicitly linked with the international male activist and antifeminist movement, I wish to show that although performing gender is at the very core of the site, it always intersects with other hierarchical differences. In addition to that, I aim to demonstrate how love is used to justify restoration of a traditional, patriarchal gender order in which the white heterosexual Western male dominates, subordinating people of any other gender, sexuality or ethnic background.
\end{abstract}

Key Words: Affects, antifeminism, blogs, cultural study of emotions, gender, intersectionality, love, masculinists, traditional gender order.

$* * * * *$

\section{Theoretical and Conceptual Background}

Love is often considered a positive emotion, an ethical, equal relationship and even a radical power that can transgress established social practices and norms. ${ }^{1}$ Romantic heterosexual love as the dominant discourse of love in Western societies is reproduced throughout contemporary culture. It has been analysed in abundance by critical theorists, cultural studies scholars and feminists, who have repeatedly demonstrated the heavy ideological burden of the romantic ideal of love as bourgeois, heteronormative and conservative. ${ }^{2}$ Some feminist critics of love have, however, shown the fluidity of love and its potential as both a modern equaliser of 
relationships and an institution that produces unequal competition between women and men in the spheres of capitalist structures. ${ }^{3}$

Whereas love as a private emotion is limited to bourgeois ideals of romantic love, it seems that the ideal of romantic heterosexual love is, besides reproduced in the private domains, simultaneously increasingly produced publicly in the digitalized contemporary culture. Assessing the blurring of public and private spheres is important in discussing love as an individual experience and an institutionally regulated form of organising emotional attachment and relationships to others. The private, or intimate, has been understood as a feminine area, whereas public has been the domain of the 'free man' ever since the dawn of democracy in Greek Antiquity. Emotions have been perceived as belonging in the private arena, rationality as a public virtue and reason as a feature of men. It is worth noting that the division into public and private spheres continues to be heavily gendered even in mediatised contemporary culture. However, the interconnectedness of private and public spheres in digitalised contemporary culture becomes evident in the blogosphere as a limitless repository of discussions and representations of love.

The idea of romantic love is closely confined to heterosexual behaviour, which is aptly described by the philosopher Judith Butler as heteronormativity. ${ }^{4}$ In Western culture heteronormativity foregrounds marriage as an institution that, according to anthropologist Edward Westermarck, is universally monogamous, connects man and wife and parents and children and arranges the relationships of men and women, adults and children as well as social life and sociability, sexuality, working life and wealth. ${ }^{5}$ In her critical analysis of marriage, professor of jurisprudence Anu Pylkkänen has shown that in regulating the life of the married couple, marriage functions more effectively in protecting property (of men) than in assuring sexual and bodily integrity and care (for women and children). ${ }^{6}$ As Dikmen Yakali suggests in her chapter in this volume, heterosexual marriage functions as the innate means of patriarchy to reproduce itself is a means to govern women in the spheres of both intimate sexuality and public working life; and that the imperative to marriage leads to compulsory heterosexuality, where the only appropriate way to live in either an intimate or a public sphere is to pair with a representative of the other $\operatorname{sex}^{7}$

Lauren Berlant's concept of intimate publics ${ }^{8}$ is useful in analysing the representations of love and marriage, as it denies the dichotomy between private and public domains and shows their intermingling. In contemporary intimate publics, the most private experiences and emotions are often thrashed out publicly in the media and increasingly on the internet. Also, the concept of semi-public has been introduced to describe the blurring of the demarcation between private and public in digitalised contemporary culture, filtered through the media. Marriage as an arrangement that organises both private and societal relations that deal with emotional attachment, welfare, taxation, succession and transnational family relations also shows the impossibility of separating the levels of social structures 
and individual emotions and experiences. ${ }^{9}$ Understood at least in secular Western societies through the romantic ideal of marriage as the arrangement of a (heterosexual) couple that deeply cares for each other, but simultaneously mixing with legislation and political economy, love is a thoroughly political concept that has the potential to affect behaviour and mobilise people. As Eva Illouz puts it, 'emotions are cultural meanings and social relationships that are very compressed together and [that] it is this compact compression which confers on them their energetic and hence their pre-reflexive, often semi-conscious character. ${ }^{10}$

In everyday understanding, gender is often understood as a bipolar system within which separate and even oppositional groups of men and women differ from and yet complement each other. Instead of the essentialist understanding of gender as an innate characteristic and the dual gender order as a 'natural' state of affairs, I understand gender, following Judith Butler, performatively: as something that is constantly produced in our repetitive daily acts. ${ }^{11}$ In this approach, gender as a given premise is problematised: I follow Iris Marion Young in taking gender 'not as an element of explanation but rather one of interpretation', and viewing love through a gendered lens, which to Young means 'seeing how a certain logic of gendered meanings and images helps organise the way people interpret events and circumstances'. ${ }^{12}$

Besides analysing the relationship between love and gender, and strategic uses of the fluid concept of love, to resist a fluid understanding of gender, I ask how the concept of love is intertwined with notions of gender, sexuality and class. I use intersectionality as my key theoretical concept and as a means to recognise hierarchically organised and constantly negotiated identity positions. Intersectional categories of gender, sexuality and social class, and the understanding of intersecting power relations as mutually constitutive, have become the focus of research in feminist theory during the past decades. ${ }^{13}$ Intersectionality as a critical concept refers to the variety of changing hierarchical positions of power that individuals take or are put into. ${ }^{14}$ In this hierarchy, 'masculine' is understood as having a higher position than 'feminine'. Bringing to the discussion other differences, such as social class, age, sexuality and ethnicity or 'race', and analysing their interdependence in positioning people in a net of power, is called intersectional analysis. Inspired by intersectionality as a methodological tool, I am not only interested in the gendered representations of love, but the intersectional aspects of love. This means focusing attention on the various and changing social categories of power that function together and simultaneously as building blocks of individual identities and delineate the ways people live their lives relationally, intermingled with others. My aim is to investigate strategic uses of love and the intersections of various identity categories in strategically using love as a means of repression by mapping the various discourses of performing gendered love on contemporary internet (semi-)publicity eagerly spread by so-called masculinists. 
During the past few years there has been a transnational upsurge of a masculinist, explicitly antifeminist movement online. In Sweden there have been internet-based hate campaigns against journalists, authors and researchers that deal with feminist issues. Besides these aggressive campaigns, masculinists in, e.g., Sweden, Finland, Canada, Germany and the United States have started to network and promote an antifeminist agenda. Also more general blogs based on masculinist ideology deal with strong emotions such as love and hate. ${ }^{15} \mathrm{I}$ am interested in how love is represented in masculinist texts published on the internet. Blogs are an extremely popular form of self-expression, and the blogosphere has become a new, democratic political arena (with the flip side of being the place for inciting racist, homophobic and misogynist atmospheres). ${ }^{16}$ It is fruitful to study the blogosphere as a snapshot of the ways of understanding, representing and performing gender in contemporary culture.

Masculinism, also referred to as men's rights activism, is 'grounded in political, economic and social power relations between men as a class and women as a class'. ${ }^{17}$ Based on the idea of the gender order as a fixed given biological fact, it refers to patriarchal ideology, 'combats feminism and the progress women have achieved' in contemporary society and is a constituent of antifeminism. ${ }^{18}$ The word masculinism carries a variety of negative connotations, such as the implicit idea that masculinism is a form of antifeminism and is as legitimate as its feminist counterpart. ${ }^{19}$ As a result, I would like to state at the outset that I am using the concept in a critical sense, denying the idea of gender equality as a zero-sum game.

Unlike masculinists, and contrary to much of the existing research in the area of social psychology that deals with heterosexual love relationships, the aim here is not to document male-female differences. ${ }^{20}$ Instead, following philosopher Luce Irigaray, I comprehend the difference between genders not as essential, but as an ethical difference. Difference is not something that should be trivialised, belittled or eliminated, but something that functions as the basis for respectful distance and fruitful dialogue of genders. When the difference between genders is understood as ethical, it becomes impossible to define women and men as the negation of or simply complementary to each other. ${ }^{21}$ A respectful gender difference is, however, impossible in our culture, where 'the space between woman and man is loaded with duties, rights, appeal, lust, owning and consuming'. ${ }^{22}$

Love, like other emotions, is socially constructed: it cannot be separated from the socio-cultural meanings that determine the way they are experienced and expressed. $^{23}$ When analysing the affective expression of the masculinists, I am interested in affects and emotions as socially constructed and performed, instead of taking them as individual psychological traits, and I wish to emphasise the intersubjective aspects of emotions: they are not only individually experienced or intrinsically situated in any one person, but are always experienced in relation to others. $^{24}$ To be more specific, I investigate the social effects of emotional expressions and the societal context of affective rhetoric and strategic uses of love. 
In doing this, I wish to deconstruct the idea of love as a utopian, exclusively positive emotion by critically analysing the ways the representations of love are used for reactionary, submissive goals in the masculinist blogosphere. In emphasising the fluidity of the uses of love, I ask how the concept of love is reframed and used as a rhetorical means to legitimise an unequal distribution of power between genders. Inspired by multidisciplinary cultural studies and feminist studies, my hypothesis is that love as a fluid and elastic concept is used strategically. In late modern society where dichotomous gender order and rigid gender roles have undergone dissolution (about the blurring of gender norms and positions, see Angela Tumini's chapter in the volume), love is used by masculinists as a repressive concept. Drawing simultaneously from the understanding of love as an emotion that arouses positive responses and from heteronormative and misogynist ideologies, the ideal of love is used by masculinists strategically to reposition women and men in the traditional gender order.

\section{Reading Masculinist Blogs on the Internet}

Love is discussed endlessly in television, pop lyrics, cinema, women's magazines and self-help literature - and in blogs and dating sites on the internet. Love has always been represented in novels and the film industry, and the contemporary self-help literature industry echoes the ideal of an enduring relationship and pure love. ${ }^{25}$ The spread of social media has nevertheless encouraged all kinds of representations of love to flourish. Representations of love range from seemingly sweet and innocent love quotes and sugary pictures of red hearts and kissing bunnies to the porn industry's objectifying photographs and videos that commercialise love to make a profit. ${ }^{26}$ There are sites promoting, e.g., LBGT rights or gender neutral marriage, but there is also a loud group of people advancing anti-immigrant, homophobic and antifeminist ideologies, whose understanding of love is, as I suggest, traditional and repressive towards all groups of people other than white heterosexual men.

Masculinism is a movement that focuses 'primarily on masculinity and the place of white heterosexual men in North American and European societies' and is 'concerned with the alleged domination of women in both the public and private spheres ${ }^{27}$ in contemporary culture, where women have entered the arenas of education and working life, and where the LGBT movement has contributed to making the boundaries between previously firm gender stereotypes more porous. This has led to a challenging of traditional assumptions about heterosexual relationships and a weakening of traditional gender roles; thus, intimate life has also been democratised ${ }^{28}$ and the man is not the self-evident head of the family. ${ }^{29}$ This poses a challenge to men, some of whom experience as a major threat the situation where, unlike Parson's concept of the functional family of the 1950s, 'the husband's instrumental leadership in the family [being] fundamentally tied to his nearly exclusive role as breadwinner' is questioned, and where the wife's offering 
to the nuclear family has spread beyond mothering and homemaking to economic contribution. ${ }^{30}$ I hope to show how masculinists, as advocates of the conservative gender order, use the positive connotations of love to promote their agenda of seeking to restore the traditional patriarchal gender order from the 1950 s when gender roles were clearly separated: men as breadwinners were the head of the family, while women as their wives served as housewives and homemakers, taking care of the children and keeping the home tidy and cosy so that both the husband and the kids would feel comfortable and 'the family would be harmonious and well-balanced'. Thus, in the nuclear family, idealised in the 'cult of home', the duty of the wife and mother was to fill the private sphere with care and love. ${ }^{31}$

Besides nostalgic yearning for the imagined 'lost paradise' of the 1950s (which actually never existed in real life), ${ }^{32}$ the most prominent themes of masculinist thinking, such as the need for men to have regular sex with women; pop evolutionary psychology; problems with fatherhood, visitation rights and maintenance allowances; men's health issues; the allegedly distorted statistics on domestic violence and equal pay, ${ }^{33}$ are summarised on the Angry Harry site, which claims to be 'one of the best-known websites frequented by those concerned with Men's Rights and by MRAs'. ${ }^{34}$ The site positions itself, striving for irony but simultaneously deadly serious, as longing for ' $[t]$ he good old days. When men were men, and when women were, as ever, complaining'. 35

Focusing the investigation on a narrow case, the Angry Harry site as explicitly heterosexual and 'white' means there is no discussion of other ethnicities or sexualities at the outset. However, during the analysis, special consideration will be directed at reading the fractures of this white heterosexual narrative. With the help of intersectionality as a methodological tool, I wish to demonstrate how identity positions, such as sexuality and class, intersect with gender in discussions dealing with love. In my analysis, I use intersectionality as the critical recognition of hierarchically organised and constantly negotiated identity positions. ${ }^{36}$ My aim is to analyse how the categories of gender, sexuality and class function together and produce each other performatively when discussing love. ${ }^{37}$ As an exception to many intersectional investigations that emphasise the mutual working of subordinating identity categories, e. g., the oppression of poor uneducated Latina women in the United States, ${ }^{38}$ my particular interest here focuses on the 'unmarked categories of power', that is, the subject positions of white middle class Western heterosexual men. ${ }^{39}$

When choosing to analyse the affective Angry Harry site, I followed Sara Ahmed's views on the influentiality of texts: when circulating in public, texts arrange and organise us by situating 'others' as the 'sources of our emotions'. The emotionality or affectivity of texts has to do with the way the texts 'move' us, and also with how emotions are performed in the texts. ${ }^{40}$ Analysing the representations of love found on a masculinist site, known for its affective, black-and-white rhetoric, misogyny - reflecting the deeply rooted cultural misogyny that Veenu 
Kakkar and Aanchal Kapur discuss in their chapter in this volume - and even hate speech towards feminists, ${ }^{41}$ I aim to analyse the understanding of love from another angle, and to uncover the representations of love that do not deal with the positive connotations of nurturing affection and care.

My method of reading is a narrative discourse analysis that enables studying the performativity of writing and the functions of linguistic choices. ${ }^{42}$ More specifically, this rhetorically-inspired close reading can be described as the 'methodology of intentional misreading', based on feminist critique of ideology. ${ }^{43}$ It is close reading that deliberately interrupts the narrative. ${ }^{44} \mathrm{By}$ 'teasing out' the meanings between the lines, I reach towards what's behind the foreseeability of these texts, through their familiarity and recognisability. As methods, the teasing and interruptive misreading mean that the researcher does not allow the dominant ways of reading to guide the interpretations, but that she leads the reading herself, asking her own questions. This method of teasing out and deliberately misreading as a form of deconstructive reading means asking disruptive and subversive questions rather than merely accepting the conclusions explicitly drawn by the text. In reading the Angry Harry site I ask: What actually is meant by love as it is understood and used by the Angry Harry bloggers? Is love gendered in the blogs? What is said about women and men and about their relationship? How are the expressions of love articulated as a subtext of the expressions of hate, resentment or subordination? How do masculinists use the ideal of love in their re-articulations of love? In other words, I am interested in the socially constructed and shared understanding of ideal love and the ideology behind its representations.

\section{Four Thematic Constellations Masculinists Use in Discussing Love}

The Angry Harry site contains essays by the writer himself, the most popular of which are 'Why Governments love feminism' and 'The psychological difference between men and women', as well as links to essays published elsewhere, such as 'Are domestic violence statistics bogus' by Wendy McElroy, ${ }^{45}$ or 'The women brainwashed by therapists to believe their parents abused them' by Amanda Gable. ${ }^{46}$ The page is structured as a blog, showing the most recently updated essay right at the top of the site. ${ }^{47}$

In the left column of the page there is an 'MRA corner' and links to, e. g., the A Voice for Men site and radio show, the Page for Men site with its rude pictures of half-naked girls in suggestive postures and a YouTube clip headed 'The real reason there aren't more female scientists', ${ }^{48}$ while in the right column glowing comments from the readers of the site are posted. Rhetorically, the site follows all the principles of populist language that relies on emotive expressions, strong polarisations and simplifications and stereotypes. It uses vague expressions and colourful metaphors and is based on juxtaposing various groups of people and constructing competing groups of 'us' and 'them'. Another central aspect of 
populist rhetoric is that it eagerly perceives threats, faults and enemies everywhere. $^{49}$

To find representations of love on the Angry Harry site, I used the 'search' command on the page and found five essays that had 'love' in the heading. They were: 'Mike Tyson - Women just love violent men' (from now on referred to as Violence); 'Feminism pros and cons: Why governments love feminism' (Government); 'Women love Manga and masculine voices' (Manga); 'Do men love to bash pregnant women?' (Bashing); and 'Do women love to do housework?' (Housework). Romantic love as a 'pure relationship ${ }^{50}$ was not in the focus of any of the writings; instead love was described as either a feeling women cannot help but have towards violent men; ${ }^{51}$ a feeling Western governments have towards feminists as their allies in creating 'as much disharmony as possible between men and women in order to fund their own empires' $;{ }^{2}$ a strong attraction of women to Manga comics as a representation of their fantasy of being raped and loving it ${ }^{53}$ or an ironical note about research on domestic violence that (allegedly falsely) reports that $17 \%$ of pregnant women have encountered domestic violence. ${ }^{54}$ Thus, 'love' seemed to be a divergent concept that often had an opportunistic undertone.

Reading these texts by teasing out the meanings of love in them, I found four thematic constellations of discourses that intertwine and overlap in the masculinist understanding of love. Each of these constellations is present in one or more of the five essays analysed here. After introducing them and looking at the intersecting differences behind the most obvious difference, namely gender difference, I will discuss their role in constructing ideal love in masculinist thought.

\section{a. The Fundamental Difference}

For Luce Irigaray, the genders should not be comprehended only in relation to each other. Instead, the idea of radical gender difference enables thinking about difference and dissimilarity without reducing woman and man to counterparts to each other. ${ }^{55}$ Contrary to this philosophical ideal, the starting point of Angry Harry is that men and women are profoundly different and thus act differently. Gender is conceived as a fundamental biological difference and a congenital difference in feminine and masculine behaviour. The masculinist understanding of genders is postulated in 'evolutionist psychology':

... the need for human beings to adapt to a hostile environment in prehistoric times resulted in men and women having different but complimentary roles and attitudes, a balance that unfortunately has been upset by feminism since the $1960 \mathrm{~s}^{56}$

The simplified pop version of evolutionist psychology means a few things for Angry Harry. One of these meanings is that men's 'hormones and sexual urges will drive them [toward being what women find attractive]'. ${ }^{57}$ Besides the obvious 
reference to sexual desire, a fundamental difference is also seen in attitudes towards housework. The reason women do more housework than men is, bluntly put, the natural gender divide: 'it is part and parcel of women's wily natures to be concerned more than men about the look of things, ${ }^{58}$ which probably has to do with the fact that 'many female mammals and birds have something within their brains akin to a nesting instinct'. ${ }^{59}$ A woman interfering with this 'natural law' of imbalance in the share of housework 'is unconsciously seeking a divorce'. ${ }^{60}$

Although binary gender difference is presented on the site as the 'normal' state of affairs and a biological fact, the dual gender order with men at the one end and women at the other is implicitly supported by the presupposition of heterosexuality. For Judith Butler, 'women' and 'men' are fraught categories that do not exist independently, but are always tied with other facets of identity, such as class, ethnicity, and sexuality. ${ }^{61}$ The argument of intersectional feminists and queer theorists that sexuality intersects inseparably with gender is supported by the famous claim of Adrienne Rich in her article on compulsory heterosexuality ${ }^{62}$ : that heterosexuality needs homosexuality to stabilise its existence, and yet, in the contemporary gender order, the lesbian existence is compulsorily denied or hidden. Thus, the idea of the fundamental difference between the two genders is used here in an intersectional manner, invoking the 'natural' sexual order, namely heterosexuality. Moreover, the assumed gender difference, emphasising the different behaviour of genders — women as easily directed by their inherent emotionality, men as 'serious' and rational, as the ancient division has it - is used as the basis of social and economic arrangements. Marriage is a perfect example of this social hierarchy produced by gender divisions that contain implicit emotional divisions, producing emotional hierarchies, which in turn implicitly organise moral and social arrangements, as Eva Illouz aptly explains. ${ }^{63}$ This assumption of the hierarchically organised emotional division of genders is implicit in the emphasis on biological difference between genders.

b. The Household as an Exchange Economy

The following description evocatively states the masculinist understanding of the place of women in society that is, indeed, straight from the 1950s white suburban ideal:

But there is nothing more arousing for a man than to peer over the top of his newspaper in order to observe closely his woman scuttling around, hither and thither, vacuuming the carpet, dusting his furniture and cleaning the windows-her pretty negligee rising and falling tantalisingly to the sensual rhythms of her labours. ${ }^{64}$ 
In the citation above, the woman is described as an intellectually immature sexual object, almost parallel to furniture, whose task is to keep the home tidy and to look desirable. In the ideology so well captured in this (perhaps intentionally) ironical statement, women get protection and shelter from their husbands in exchange for sexual and domestic services. In my earlier readings of texts by Finnish masculinists, namely a blog by media celebrity Henry Laasanen ${ }^{65}$ and an essay collection by poet and essayist Timo Hännikäinen, ${ }^{66}$ I found similarities in the emotionless tone of their texts: positive feelings such as love are not discussed, but instead, the idea of hetero-sex as an exchange of commodities, inspired by neoliberalism, penetrates the texts. This is not only a characteristic of masculinist ideology, but more broadly a feature of what Max Weber called the spirit of capitalism, which has been conceptualised in the commercialisation of intimate life as described by Arlie Hochschild. ${ }^{67}$

Although this citation from the Angry Harry site uses affective expressions in depicting a harmonious heterosexual idyll, it perpetuates the idea of women trading sexual services for protection and economic upkeep that is widely circulated in masculinist texts. ${ }^{68}$ The tendency to see women in need of protection follows the patriarchal logic in which 'the role of the masculine protector puts those protected, paradigmatically women and children, in a subordinate position of dependence and obedience' and legitimates authoritarian power to the man as the head of the family. ${ }^{69}$ The logic of masculinism, as Iris Marion Young has it, 'associates with the position of male head of household as a protector of the family, and, by extension, with masculine leaders and risk takers as protectors of a population'. ${ }^{70}$

The idea of men and women as classes originally emerged in the theorisations of feminist thinkers such as Zillah Eisenstein, who understood gender as a social class. In her theorisation, men and women as classes are organised hierarchically: men dominate, while women are subordinated. ${ }^{71}$ The principal means of controlling and governing the lower class is economic exploitation, through which women are forced to be housewives, raise children and serve men without pay. Thus, marriage — although validated with love — is based on economic subordination and sustains the personal and universal dependency of women on men. $^{72}$

In Angry Harry's opinion, on the contrary, Western women have done well, as they 'live as the most pampered, the most protected, the most catered for and the most over-indulged organisms ever to have existed on the planet. ${ }^{73}$ Thus economic issues are discussed explicitly under the ideal of heterosexual love - although the underlying assumption that the readers of the blog are middle-aged and the internalisation of the Western ideal of the nuclear family are not discussed. However, feminists now pose a threat to marriage as the natural way of arranging relationships.

c. Feminism as a Threat to Marriage, Family and Society 
Masculinist texts utilise an affective tone, often slanted by anger and resentment. ${ }^{74}$ This is evident in Angry Harry's texts as well, as can be seen in this excerpt:

Feminist hysteria, disinformation and intimidation all ensure that women in this society are held responsible for very few of the many negative things they, themselves, cause to happen. ${ }^{75}$

The feminist threat is rhetorically produced as a counterpoint to the paradiselike, harmonious society, which is created when men and women fulfil their social roles, described by affectively appealing to its positive aspects:

[...] imagine a society — a somewhat idealised society wherein the women are happy to spend their days being closely associated with their homes and with their children, while the young men and the fathers are reasonably happy to troop off to the workplace $[\ldots]^{76}$

However, the setting loses its balance because 'the main aim for feminists is to create as much disharmony as possible between men and women, ${ }^{77}$ leading to divorce, which leads to 'a whole cascade of social problems [because] the youngsters [are] not having fathers around' ${ }^{78}$ Marriage and its erosion also causes "hatred towards men and a fear of men', ${ }^{79}$ not to even mention that 'vulnerable 'people [besides children, the elderly and the sick] are either abandoned to waste away on their own, or they are put into care homes and hospitals' ${ }^{80}$ All this is caused by the alliance between feminists and the government — 'the perfect hammer for smashing up people's relationships ${ }^{, 81}$ - that forces families to break up by encouraging women to divorce, 'breaking apart the relationships between men and women and men and children', encouraging 'excessive immigration' and by enacting "laws to do with hate speech and with "offending people" which 'distance people from each other'. ${ }^{82}$

Constructing feminism and feminists as a threat follows, as Iris Marion Young has it, the logic of masculinist protection that often constitutes the 'good' men who protect their women and children, in opposition to other 'bad' men who are liable to attack. In this logic, virtuous masculinity depends on its constitutive relation to the presumption of evil others. Here, those others are not (ethnically, socially or in other ways) other men, but feminists. There is, thus, a correlate dichotomy between the 'good' woman and the 'bad' woman. To cite Young:

Simply put, the 'good' woman stands under the male protection of a father or a husband, submits to his judgment about what is necessary for her protection, and remains loyal to him. A 'bad' woman is one who is 
unlucky enough not to have a man willing to protect her, or who refuses such protection by claiming the right to run her own life. In either case, the woman without a male protector is fair game for any man to dominate. There is a bargain implicit in the masculinity protector role: either submit to my governance or all the bad men out there are liable to approach you, and I will not try to stop them. ${ }^{83}$

On the Angry Harry site, feminists as bad women are positioned as a threat to those good women who want to stay at home, pampering their husbands and children. Power and subordination are thus brought up in the blogs under the disguise of heterosexual love, and the worst threat seems to be the equal rights of women to go to work and to earn their own salary. Intersecting power hierarchies of gender, economic situation, social status and education are here in operation par excellence.

\section{d. The Defence of Male Violence}

In three out of the five essays analysed here, Angry Harry argues, somewhat surprisingly in the context of discussing love, for a close link between sexuality and violence. In all these essays violent and aggressive men are described as the subjects of female fantasies: 'Mike Tyson would click his fingers at one of the gorgeous young women in the queue, and she would be the one honoured with his bed for the night. ${ }^{, 84}$ The alleged female worshipping of 'arrogant, loud-mouthed, muscular, boundary-breaking men' who 'perform aggressively and rudely' ${ }^{85}$ leads to male violence, because 'men, statistically speaking, will drift toward being whatever it is that women find attractive'. ${ }^{86}$ Based on this evolutionary claim, a shift of perspective is executed:

[...] instead of simply blaming men for their propensity toward violence, one might take notice of the fact that significant numbers of women encourage it, and get turned on by it. ${ }^{87}$

A similar logic of making excuses for male violence is found in the essay about Manga, the main argument of which is a generalisation based on the claim that rape fantasy expressed in Manga comics is popular among Japanese women: 'many women just love the idea of being abused. They love it. ${ }^{, 88}$

The argument goes as follows: Gradually, men learn to behave according to 'women's ubiquitous rape fantasies', using 'aggression as a means of making women feel good', ${ }^{89}$ but this turns out to be dangerous because, in Angry Harry's world, there are women like Little Miss Victim or Vengeful Alice. They also have fantasies about rape, but for some reason after intercourse they change their mind regarding the enjoyment caused by aggressive sexual behaviour and charge the innocent man with rape. ${ }^{90}$ 
In the essay dealing with bashing pregnant women, pregnancy changes the power relations of the heterosexual relationship, for now 'her partner not only ceases to be the centre of her universe, he quickly turns into not much more than an implement for achieving her aims. Most of the animal kingdom seems to operate in this fashion'. ${ }^{91}$ The argumentation continues:

As a result, [men] often feel very insecure and threatened by [pregnancy]. Further, they often feel that they have been duped, and lied to, because of the dramatic changes in their partners' attitudes toward them - hence the violence. ${ }^{92}$

Besides justification of domestic violence conducted by men - 'the more men are disempowered within their relationships, the more will men and women tend to end up reacting toward each other with aggression ${ }^{, 93}$ — the essay tries to prove that statistics on domestic violence lie, hiding of course, the power hierarchies of gender and physical ability.

\section{Conclusions and Discussion}

The four thematic constellations introduced above indicate the various strategic uses of love in masculinist thought. The last quote above proves their intertwining, bringing together the evolutionary psychological explanation, the crisis of men and the breakdown of the traditional heterosexual partnership, and the erosion of the patriarchal idea about the man as the head of the family, all wrapped up in a package of affective rhetoric. In an exemplary way, the citation describes the change in the status of white middle class heterosexual male in contemporary culture.

Advocating the traditional gender order, masculinists use the concept of love to promote the repressive ideas of misogynist and antifeminist ideologies. My hypothesis was that love is used as a justification of the restoration of the traditional, patriarchal gender order, within which the white heterosexual Western male dominates, subordinating people of any other gender, sexuality or ethnic background. This did not happen quite as expected. Indeed, love was actually mainly discussed outside the context of heterosexual romantic relationships. For Angry Harry, using the concept of love is a stylistic choice, a tool for creating tension between men as the victims of modernisation and destructive feminists. Thus, it is not a numinous force that can elevate us above the mundane, but rather a notion loaded with irony.

In my previous readings of renowned Finnish masculinists, I found similarities in the texts of a blogger and a poet: positive feelings such as love are not discussed, but instead, there is the capitalist, neoliberal idea about hetero-sex as an exchange of commodities. ${ }^{94}$ My analysis of the representations of love in the texts by Angry 
Harry supports my previous findings, although love as a theme is more explicitly dealt with here. In Angry Harry's blog, too, love is a commodity that is bought, sold and traded. And yet, when scratching the surface of the site, performing love is at the very core of the blog. It is done by juxtaposing men and women, reinforcing a traditionalist view of gender roles, and in the context of a narrow understanding of love as heterosexual and monogamous. Patriarchal ideology holds, as 'love' is used to tie women to their roles as wives, mothers and homemakers. However, intersectionality adds another layer to the interpretations: it is not only gender, but also the heteronormative white bourgeois way of strategically using love as a means to make women stay at home by appealing to their 'inner nature' as pampering parents.

Furthermore, what is worth noting is that love is obviously not only a genre for escapist entertainment directed at teenage girls and women. Men also seek love, although it has been suggested by Jorgen Lorentzen that 'love is not at all an important part of heterosexual men's lives', who 'work hard to embody the masculine ideal, to be admired for their physical, financial and political strength, which will guarantee them a certain kind of love from people who fit into and enhance their masculine image'. For de Beauvoir, these 'serious men' 'reproduce their patriarchal versions of love in all forms of intimate relationships'. ${ }^{95}$ The argument would find support in other texts, besides de Beauvoir, such as in Anthony Giddens' idea of men behaving according to the pre-modern family system even though as a culture, we have moved to a different mode of organising family relations, whereas women have adopted the post-modern mode, where intimate relations and reflecting one's emotions have become indispensable. ${ }^{96}$

All in all, the advocates of the traditional gender order use the positive connotations of love to promote the repressive ideas of misogynist, antifeminist and heterosexist ideologies on the internet. It is noteworthy that this understanding of love as a pure, altruistic and noble emotion is not limited to masculinists. Feminist thinkers such as Adrienne Rich have argued that the very notion of love as idealized perpetuates female subordination., Albeit the discussion analysed here is only a narrow and fragmentary example of the subordination of women in the name of love, the influence of the masculinist movement is becoming more pervasive over the internet, in addition to traditional print and digital media. Thus, the masculinist reconceptualisation of love as a gendered concept that is ideologically loaded as an adjunct to male conquest of women is worth studying. And yet, while studying the fixed uses of love, it should not be forgotten that love as a fluid concept also includes the potential of optimism, change and transformation that is capable of challenging the rigid norms and repressive regulations of established institutions such as heterosexual marriage. ${ }^{97}$

\section{Notes}


${ }^{1}$ Renata Grossi, 'Romantic Love - a Feminist Conundrum?' (The Feminist Wire 2013, viewed 9 October 2015.

http://thefeministwire.com/2013/feminist-critiques-of-love/).

2 Simone de Beauvoir, Le Deuxième Sexe (Paris: Gallimard, 1949); Shulamit Firestone, The Dialectic of Sex: The Case for Feminist Revolution (New York: William Morrow, 1970); Marilyn Friedman, What Are Friends For? Feminist Perspectives on Personal Relationships on Moral Theory (Ithaca: Cornell University Press, 1994); Carol Smart. Regulating Womanhood: Historical Essays on Marriage, Motherhood, and Sexuality (London and New York: Routledge, 1992).

${ }^{3}$ Eva Illouz, Cold Intimacies. The Making of Emotional Capitalism (Cambridge: Polity Press, 2007).

${ }^{4}$ Judith Butler, Gender Trouble. Feminism and the Subversion of Identity (New York and London: Routledge, 1990).

${ }^{5}$ Edward Westermarck, The History of Human Marriage (London and New York: McMillan, 1891), 271. Cited in Soile Veijola and Eeva Jokinen, Voiko naista rakastaa? Avion ja eron karuselli [Can a Woman Be Loved? The Merry-go-round of Marriage and Divorce] (Helsinki: WSOY: 2001), 19. Note that marriage organizes not only the life of the married, but also the unmarried 'yet, any more, or at the moment', because it is the underlying presupposition of how to live (ibid.).

6 Anu Pylkkänen, Vaihtoehto avioliitolle, Seksuaalisuudesta yhteistalouden säätelyyn [An Alternative to Marriage: From Sexuality to Collective Economy] (Tampere: Vastapaino, 2012), 13.

${ }^{7}$ Veijola and Jokinen, Voiko naista rakastaa, 84-85; 95.

${ }^{8}$ Lauren Berlant, The Female Complaint. The Unfinished Business of Sentimentality in American Culture (Durham: Duke University Press, 2008).

${ }^{9}$ Pylkkänen, Vaihtoehto avioliitolle, 24.

${ }^{10}$ Illouz, Cold Intimacies, 3.

${ }^{11}$ Butler, Gender Trouble.

${ }^{12}$ Iris Marion Young, 'The Logic of Masculinist Protection: Reflections on the Current Security State'. Signs: Journal of Women in Culture and Society (29: 1, 2003), 1-25.

${ }^{13}$ Kimberlé Crenshaw, 'Mapping the Margins: Intersectionality, Identity Politics, and Violence against Women of Color' (Stanford Law Review 43, 6, 1991), 12411299; Ann Phoenix and Pamela Pattynama, 'Intersectionality' (European Journal of Women's Studies, 13: 3, 2006), 187-192.

${ }^{14}$ Tuuli Lähdesmäki and Tuija Saresma, 'Re-framing Gender Equality in Finnish Online Discussion on Immigration: Populist Articulations of Religious Minorities and Marginalized Sexualities' (NORA - Nordic Journal of Feminist and Gender 
Research, 22:4 2014), 299-313. Published on-line at http://www.tandfonline.com/eprint/DTPxdkWhaXZKysEku2PK/full, DOI: 10.1080/08038740.2014.953580.

15 Malin Holm, 'Men Who Hate Women - Online. Mapping the Swedish AntiFeminist Movement in the New Media' (Draft paper prepared for the 2013 ECPG Conference, Barcelona, Spain, 2013).

${ }^{16}$ Michael Keren, Blogosphere. The New Political Arena (Lanham: Lexington Books, 2006); Cass R. Sunstein, C. R., http://Republic.com 2.0 (Princeton University Press, 2007).

17 Melissa Blais and Francis Dupuis-Déri, 'Masculinism and the Antifeminist Countermovement' (Social Movement Studies 11: 1, 2012), 25.

${ }^{18}$ Blais and Dupuis-Déri, 'Masculinism'.

${ }^{19}$ Blais and Dupuis-Déri, 'Masculinism', 23.

${ }^{20}$ Letitia Anne Peplau and Steven L. Gordon, 'Women and Men in Love: Gender Differences in Close Heterosexual Relationships.' In EV: E. O'Leary, R. K. Unger, and B. S. Wallston (eds.), Women, Gender, and Social Psychology (Hillsdale, NJ: Lawrence Erlbaum, 1985), 258.

21 Luce Irigaray, J'aime à toi. Esquisse d'une félicité dans l'histoire. Paris: Éditions Grasset and Fasquelle, 1992, cited in Veijola and Jokinen, Voiko naista rakastaa, 21.

${ }^{22}$ Veijola and Jokinen, Voiko naista rakastaa, 22.

${ }^{23}$ McCarthy, E. Doyle, "The Social Construction of Emotions: New Directions from Culture Theory" (Sociology Faculty Publications. Chapter 4, 1994), http://fordham.bepress.com/soc_facultypubs/4; Deborah Lupton, The Emotional Self. A Sociocultural Explanation (London: Sage, 1998); Richard Sennett, Together. The Rituals, Pleasures and Politics of Cooperation (London: Allen Lane/Penguin Books, 2012).

${ }^{24}$ Sara Ahmed, The Cultural Politics of Emotion (Edinburgh and London: Edinburgh University Press and Routledge, 2004), 2.

${ }^{25}$ Annukka Lahti, 'Similar and Equal Relationships? Negotiating Bisexuality in an Enduring Relationship.' Feminism and Psychology (published online doi: 10.1177/0959353515574786, 2015. Read 12 October 2015).

${ }^{26}$ E.g. viewed 1 September 2014, http://www.brainyquote.com/quotes/topics/topic_love.html.

${ }^{27}$ Blais and Dupuis-Déri, 'Masculinism', 23.

${ }^{28}$ Jeffrey Weeks, The World We Have Won: The Remaking of Erotic and Intimate Life (New York: Routledge, 2007).

${ }^{29}$ Peplau and Gordon, 'Women and Men in Love', 258. 
${ }^{30}$ Talcott Parsons, 'The American Family. Its Relations to Personality and to the Social Structure.' In T. Parsons and R. F. Bales. Family, Socialization and Interaction Process (Glencoe, Ill.: Free Press, 1955). Cited in Peplau and Gordon, 268.

${ }^{31}$ Kirsi-Maria Hytönen and Keijo Rantalainen (eds.), Onnen aika. Valoja ja varjoja 1950-luvulla [The Time of Happiness. Lights and Shadows in the 1950s] (Jyväskylä: Atena, 2013).

32 Tuija Saresma, 'Maskulinistiblogi feministidystopiana ja kolonialistisena pastoraalina [The Masculinist Blog as a Feminist Dystopia and a Colonial Pastorale]. In Tuija Saresma and Saara Jäntti (eds.), Maisemassa. Sukupuoli ja kansallisuus suomalaisuuden kuvastoissa [In the landscape: Gender and Nationality in the Imageries of Finnishness] (Jyväskylä: Nykykulttuurin tutkimuskeskus, 2014a), 249-284.

33 Tuija Saresma, 'Miesten tasa-arvo ja kaunapuhe blogikeskustelussa' [The Equality of Men and Resentment Speech in a Blog Discussion]. Sukupuoli nyt! Purkamisia ja neuvotteluja [Gender Now! Deconstruction and Negotiation], edited by Hannele Harjunen and Tuija Saresma (Jyväskylä: Kampus Kustannus, 2012), 13-34.; Saresma, Tuija. 'Sukupuolipopulismi ja maskuliininen standpointempirismi' [Gender populism and standpoint empiricism] (Sukupuolentutkimus Genusforskning 2 2014b), 46-53.

${ }^{34}$ Viewed 1 September 2014, www.angryharry.com. MRAs is an abbreviation of Men Rights Activists.

${ }^{35}$ Housework, 2.

${ }^{36}$ Lähdesmäki and Saresma, 'Re-framing Gender Equality in Finnish Online Discussion on Immigration: Populist Articulations of Religious Minorities and Marginalized Sexualities', NORA, 299-313.

${ }^{37}$ Sanna Karkulehto, et al, 'Intersektionaalisuus metodologiana ja performatiivisen intersektionaalisuuden haaste' [Intersectionalty as a Methodology and the Challenge of Performative Intersectionality] (Naistutkimus - Kvinnoforskning 25: 4, 2012), 17-28.

${ }^{38}$ Crenshaw, 'Mapping the Margins'.

39 Hae Yoen Choo and Myra Marx Ferree, 'Practicing Intersectionality in Sociological Research: A Critical Analysis of Inclusions, Interactions, and Institutions in the Study of Inequality' (Sociological Theory 28: 2, 2010), 129-149.

${ }^{40}$ Ahmed, Cultural Politics of Emotion, 1; 13.

41 Maria Sveland, Hatet. En bok om antifeminism [Hatred. A Book on Antifeminism] (Stockholm: Leopard Förlag, 2013).

${ }^{42}$ Ernesto Laclau, On Populist Reason (London, Verso, 2005).

${ }^{43}$ Gayatri Chakravorty Spivak, In Other Worlds. Essays in Cultural Politics (New York: Routledge, 1987). 
${ }^{44}$ Veijola and Jokinen, Voiko naista rakastaa, 34.

45 Viewed 1 September 2014, http://reason.com/archives/2014/02/22/aredomestic-violence-statistics-bogus.

46 Viewed 1 September 2014, http://www.dailymail.co.uk/femail/article2555392/The-women-brainwashed-therapists-believe-parents-abusedthem.html\#ixzz3C3kKZ8BD.

${ }^{47}$ The site can be found at http://www.angryharry.com/index.html.

$48 \mathrm{http}: / / \mathrm{www}$.avoiceformen.com/; http://www.pageformen.com/.

49 Lähdesmäki and Saresma, 'Re-framing Gender Equality'.

50 Anthony Giddens, The Transformation of Intimacy. Sexuality, Love and Eroticism in Modern Societies (Oxford and Cambridge: Polity Press, 1992).

${ }^{51}$ Angry Harry, Women just love violent men [from now on, Violence], viewed 1 September 2014, http://www.angryharry.com/esWomenJustLoveViolentMen.htm. ${ }^{52}$ Violence.

${ }^{53}$ Angry Harry, Women Love Manga [from now on, Manga], viewed 1 September 2014, http://www.angryharry.com/esWomenLoveManga.htm.

${ }^{54}$ Angry Harry, Men love to bash Pregnant Women [from now on, Bashing], $\begin{array}{llll}\text { viewed } & 1 & \text { September }\end{array}$ http://www.angryharry.com/esMenlovetobashpregnantwomen.htm?note.

55 Irigaray, J'aime à toi, 65-86, cited in Eva Maria Korsisaari, Tule, rakkaani! Naisen ja miehen välisestä etiikasta kirjallisuuden rakkauskuvauksissa [Come, My Love! On the Ethics between a Woman and a Man in the Literary Depictions of Love] (Helsinki: Teos, 2006), 177-178.

${ }^{56}$ Blee and Dupuis-Déri, 'Masculinism', 24.

${ }^{57}$ Violence, 3.

58 Angry Harry, Women Love Housework [from now on, Housework], viewed 1 September 2014,. http://www.angryharry.com/eshousework.htm?note.

${ }^{59}$ Housework, 4.

${ }^{60}$ Housework, 4.

${ }^{61}$ Butler, Gender Trouble.

${ }^{62}$ Adrienne Rich, 'Compulsory Heterosexuality and Lesbian Existence (Signs 5:

4), 631-660.

${ }^{63}$ Illouz, Cold Intimacies, 3.

${ }^{64}$ Housework , 4.

${ }^{65}$ Saresma, 'Maskulinistiblogi'.

${ }^{66}$ Saresma, 'Kauna'.

${ }^{67}$ Arlie Russel Hochschild, The Commercialization of Intimate Life: Notes from Home and Work (Los Angeles: California University Press, 2003).

${ }^{68}$ Saresma, 'Maskulinistiblogi'.

${ }^{69}$ Young, 'Masculinist Protection', 2. 
${ }^{70}$ Young, 'Masculinist Protection' 3.

${ }^{71}$ Zillah Eisenstein, 'Constructing a Theory of Capitalist Patriarchy and Socialist Feminism' (Critical Sociology 2/3, 1995), 196-217.

${ }^{72}$ Veijola and Jokinen, Voiko naista rakastaa, 93.

${ }^{73}$ Housework, 2.

${ }^{74}$ Saresma, 'Maskulinistiblogi'.

${ }^{75}$ Violence, 4.

${ }^{76}$ Angry Harry, Why Governments Love Feminism [from now on, Government], viewed 1 September 2014 , http://www.angryharry.com/esWhyGovernmentsLoveFeminism.htm.

${ }^{77}$ Government, 3 .

${ }^{78}$ Government, 5 .

${ }^{79}$ Government, 7 .

${ }^{80}$ Government, 6 .

${ }^{81}$ Government, 16.

${ }^{82}$ Government, 15.

${ }^{83}$ Young 13-14.

${ }^{84}$ Violence, 1.

${ }^{85}$ Violence, 2.

${ }^{86}$ Violence, 3.

${ }^{87}$ Violence, 4.

${ }^{88}$ Manga, 2.

${ }^{89}$ Manga, 3.

${ }^{90}$ Manga, 3-6.

${ }^{91}$ Bashing, 1.

92 Bashing, 2.

${ }^{93}$ Bashing, 9.

${ }^{94}$ Saresma 'Maskulinistiblogi'; Saresma 'Sukupuolipopulismi'.

${ }^{95}$ Leo Mundy, 'The Question of Men in Love: a Beauvoirian response to Jørgen Lorentsen' (NORA - Nordic Journal of Feminist and Gender Research 23: 3, 2015), 187-202.

${ }^{96}$ Giddens, Transformations of Intimacy.

${ }^{97}$ Berlant, 'Intimacy'.

\section{Bibliography}

Ahmed, Sara. The Cultural Politics of Emotion. Edinburgh and London: Edinburgh University Press and Routledge, 2004. 
de Beauvoir, Simone. Le Deuxième Sexe. Paris: Gallimard, 1949.

Berlant, Lauren. 'Intimacy. A Special Issue.' Critical Inquiry 24 (1998): 2, 281288.

Berlant, Lauren. The Female Complaint. The Unfinished Business of Sentimentality in American Culture. Durham: Duke University Press, 2008.

Blais, Melissa and Dupuis-Déri, Francis. 'Masculinism and the Antifeminist Countermovement,' Social Movement Studies 11, 1 (2012), 21-39.

Butler, Judith 1990. Gender Trouble. Feminism and the Subversion of Identity. New York and London: Routledge.

Choo, Hae Yeon and Marx Ferree, Myra. 'Practicing Intersectionality in Sociological Research: A Critical Analysis of Inclusions, Interactions, and Institutions in the Study of Inequality.' Sociological Theory 28 (2010): 2, 129-149.

Crenshaw, Kimberlé. 'Mapping the Margins: Intersectionality, Identity Politics, and Violence against Women of Color,' Stanford Law Review 43, 6 (1991): 12411299.

Eisenstein, Zillah, 'Constructing a Theory of Capitalist Patriarchy and Socialist Feminism (Critical Sociology 2/3, 1995), 196-217.

Giddens, Anthony, The Transformation of Intimacy. Sexuality, Love and Eroticism in Modern Societies. Oxford and Cambridge: Polity Press, 1992.

Grossi, Renata. 'Romantic Love - a Feminist Conundrum?' 2013, http://thefeministwire.com/2013/feminist-critiques-of-love/, read 9.10.2015.

Firestone, Shulamith. The Dialectic of Sex: The Case for Feminist Revolution. New York: William Morrow, 1970.

Friedman, Marilyn. What Are Friends For? Feminist Perspectives on Personal Relationships on Moral Theory. Ithaca: Cornell University Press, 1994.

Hochschild, Arlie Russel. The Commercialization of Intimate Life: Notes from Home and Work. Los Angeles: California University Press, 2003. 
Holm, Malin. 'Men who hate women - Online. Mapping the Swedish AntiFeminist Movement in the New Media.' Draft paper prepared for the 2013 ECPG Conference, Barcelona, Spain, 2013.

Hytönen, Kirsi-Maria and Rantalainen, Keijo (eds.). Onnen aika. Valoja ja varjoja 1950-luvulla [The Time of Happiness. Lights and Shadows in the 1950s]. Jyväskylä: Atena, 2013.

Irigaray, Luce. J'aime à toi. Esquisse d'une félicité dans l'histoire. Paris: Éditions Grasset and Fasquelle, 1992.

Karkulehto, Sanna, Saresma, Tuija, Harjunen, Hannele and Johanna Kantola, 'Intersektionaalisuus metodologiana ja performatiivisen intersektionaalisuuden haaste' [Intersectionality as a Methodology and the Challenge of Performative Intersectionality], Naistutkimus - Kvinnoforskning 25: 4, 2012, 17-28.

Korsisaari, Eva Maria. Tule, rakkaani! Naisen ja miehen välisestä etiikasta kirjallisuuden rakkauskuvauksissa [Come, My Love! On the Ethics between a Woman and a Man in the Literary Depictions of Love]. Helsinki: Teos, 2006.

Keren, Michael. Blogosphere. The New Political Arena. Lanham: Lexington Books, 2006.

Laclau, Ernesto. On Populist Reason. London: Verso, 2005.

Lupton, Deborah. The Emotional Self. A Sociocultural Explanation. London: Sage, 1998.

Lähdesmäki, Tuuli and Saresma, Tuija. 'Re-framing gender equality in Finnish online discussion on immigration: Populist articulations of religious minorities and marginalized sexualities.' NORA - Nordic Journal of Feminist and Gender Research, 22:4 (2014), 299-313. Published on-line at http://www.tandfonline.com/eprint/DTPxdkWhaXZKysEku2PK/full, DOI: 10.1080/08038740.2014.953580.

McCarthy, E. Doyle. 'The Social Construction of Emotions: New Directions from Culture Theory'. Sociology Faculty Publications. Chapter 4, 1994, http://fordham.bepress.com/soc_facultypubs/4 
Mundy, Leo. 'The Question of Men in Love: A Beauvoirian Response to Jorgen Lorentzen.' NORA - Nordic Journal of Feminist and Gender Research 23: 3, 2015, 187-202.

Parsons, Talcott. 'The American Family. Its relations to Personality and to the Social Structure.' In T. Parsons and R. F. Bales. Family, Socialization and Interaction Process, 3-33. Glencoe, Ill.: Free Press, 1955.

Peplau, Letitia Anne and Gordon, Steven L. 'Women and Men in Love: Gender Differences in Close Heterosexual Relationships.' In EV: E. O'Leary, R. K. Unger, and B. S. Wallston (eds.), Women, Gender, and Social Psychology, 257-291. Hillsdale, NJ: Lawrence Erlbaum, 1985.

Phoenix, Ann and Pattynama, Pamela. 'Intersectionality,' European Journal of Women's Studies, 13: 3, 2006,,pp. 187-192.

Pylkkänen, Anu. Vaihtoehto avioliitolle. Seksuaalisuudesta yhteistalouden säätelyyn. Tampere: Vastapaino, 2012.

Rich, Adrienne. 'Compulsory Heterosexuality and Lesbian Existence'. Signs 5: 4, pp. 631-660.

Saresma, Tuija. 'Miesten tasa-arvo ja kaunapuhe blogikeskustelussa.' Sukupuoli nyt! Purkamisia ja neuvotteluja [Gender now! Deconstruction and negotiation], edited by Hannele Harjunen and Tuija Saresma, 13-34. Jyväskylä: Kampus Kustannus, 2012.

Saresma, Tuija. 'Maskulinistiblogi feministidystopiana ja kolonialistisena pastoraalina [The masculinist blog as a feminist dystopia and a colonial pastorale]. In Tuija Saresma and Saara Jäntti (eds.), Maisemassa. Sukupuoli ja kansallisuus suomalaisuuden kuvastoissa [In the landscape: Gender and nationality in the imageries of Finnishness], 249-284. Jyväskylä: Nykykulttuurin tutkimuskeskus, 2014 (a).

Saresma, Tuija. 'Sukupuolipopulismi ja maskuliininen standpoint-empirismi' [Gender populism and standpoint empiricism]. Sukupuolentutkimus Genusforskning 2: 2014 (b), 46-53.

Saresma, Tuija. 'Kauna Timo Hännikäisen kokoelmassa Ilman - esseitä seksuaalisesta syrjäytymisestä [Resentment in Timo Hännikäinen's collection 
Without - Essays on Sexual Displacement], in Anna Helle and Anna Hollsten (eds.), Tunteet ja tuntemukset suomalaisessa kirjallisuudessa [Emotions and Affects in Finnish Literature]. Helsinki: SKS (forthcoming).

Sennett, Richard. Together. The Rituals, Pleasures and Politics of Cooperation. London: Allen Lane/Penguin Books, 2012.

Smart, Carol. Regulating Womanhood: Historical Essays on Marriage, Motherhood, and Sexuality. London and New York: Routledge, 1992.

Spivak, Gayatri Chakraworty. In Other Worlds. Essays in Cultural Politics. New York: Routledge, 1987.

Sunstein, C. R. http://Republic.com 2.0. Princeton: Princeton University Press, 2007.

Sveland, Maria. Hatet. En bok om antifeminism. Stockholm: Leopard Förlag, 2013.

Veijola, Soile and Jokinen, Eeva. Voiko naista rakastaa? Avion ja eron karuselli. Helsinki: WSOY, 2001.

Weeks, Jeffrey. The World We Have Won: The Remaking of Erotic and Intimate Life. New York: Routledge, 2007.

Westermarck, Edward. The History of Human Marriage. London and New York: McMillan, 1891.

Young, Iris Marion. 'The logic of Masculinist Protection: Reflections on the Current Security State,'Signs: Journal of Women in Culture and Society 29, 1 (2003), 1-25.

Tuija Saresma, $\mathrm{PhD}$, Docent/Adjunct Professor, is a Senior Researcher in the Department of Art and Culture Studies at the University of Jyväskylä, Finland, and the Principal Investigator of the 'Arts of Belonging - Affectivity and Materiality of Homing' Research Project, funded by Kone foundation. This chapter is part of a 'Populism as movement and rhetoric' research project, funded by the Academy of Finland (SA21000019101). 
